\title{
Determinan Peningkatan Pembangunan Manusia Di Sumatera Utara
}

\author{
Rita Herawaty Bangun1) \\ 1)Fungsional Statistisi BPS Provinsi Sumatera Utara, Indonesia \\ Diterima Februari, 2020; Disetujui April, 2020; Dipublikasikan Juni, 2020
}

\begin{abstract}
Abstrak
Indeks pembangunan manusia (IPM) merupakan salah satu indikator yang digunakan untuk mengukur pencapaian kualitas hidup pembangunan manusia. Capaian pembangunan manusia Sumatera Utara pada tahun 2018 berada di kategori tinggi. Peningkatan capaian IPM di Sumatera Utara perlu dilakukan sebagai implementasi tujuan pembangunan manusia berkelanjutan dengan memperhatikan faktorfaktor pendukungnya. Tujuan penelitian ini adalah untuk menganalisis dan mengidentifikasi faktorfaktor yang berpengaruh terhadap peningkatan capaian IPM di Provinsi Sumatera Utara. Penelitian ini menggunakan data kerat lintang yang terdiri dari data jumlah penduduk miskin, tingkat pengangguran terbuka (TPT) dan produk domestik regional bruto (PDRB) atas dasar harga berlaku menurut wilayah kabupaten dan kota pada tahun 2018. Penelitian ini menggunakan teknik analisis linier berganda. Hasil penelitian membuktikan bahwa variabel jumlah penduduk miskin, tingkat pengangguran terbuka, dan PDRB atas dasar harga berlaku secara bersama-sama memberikan pengaruh terhadap peningkatan IPM. Secara partial variabel jumlah penduduk miskin dan PDRB atas dasar harga berlaku berngaruh terhadap peningkatan IPM sedangkan variabel tingkat pengangguran terbuka tidak berpengaruh secara signifikan.
\end{abstract}

Kata Kunci: IPM, Kemiskinan, PDRB, Pengangguran

\begin{abstract}
Human development index (HDI) is one indicator used to measure the achievement of the quality of life for human development. The human development achievements of North Sumatra in 2018 are in the high category. Improving the achievement of HDI in Sumatra Utara needs to be done as an implementation of sustainable human development goals by taking into account the supporting factors. The purpose of this study is to analyze and identify the factors that influence the increase in HDI in Sumatra Utara. This study uses cross-section data consisting of data on the number of poor people, open unemployment rates, and gross regional domestic product (GRDP) at current prices by district and city in 2018. This study uses multiple linear analysis techniques. The results showed that the variable number of poor people, open unemployment rates, and GRDP at current prices jointly affected increasing HDI. Partially the number of poor populations and the GRDP at the base price prevailed to increase the HDI while the open unemployment rate variable had no significant effect.
\end{abstract}

Keywords: HDI, Open Employment Rates, PDRB, Poverty

How to Cite: Bangun, H.R. (2020). Determinan Peningkatan Pembangunan Manusia Di Sumatera Utara. PUBLIKAUMA: Jurnal Ilmu Administrasi Publik UMA, Vol 8 (1): 32-29

*Corresponding author: ISSN 2549-9165 (Print)

E-mail: rita.bangun@bps.go.id ISSN 2580-2011 (Online) 


\section{PENDAHULUAN}

Salah satu indikator yang digunakan untuk melihat keberhasilan dalam upaya pembangunan kualitas hidup masyarakat adalah Indeks Pembangunan Manusia (IPM). Menurut (Melliana \& Zain, 2013) menjelaskan bahwa IPM digunakan untuk mengukur kualitas hidup manusia dari sisi dampaknya terhadap kondisi fisik manusia dan non fisik. Selanjutnya (Juliarini, 2019) berpendapat bahwa IPM yang tinggi menunjukkan kesejahteraan masyarakat yang tinggi. IPM dapat memberikan gambaran hasil pelaksanaan pembangunan manusia berdasarkan tiga aspek yaitu aspek kesehatan yang diukur melalui umur harapan hidup, aspek pendidikan diukur melalui harapan lama sekolah dan rata-rata lama sekolah serta aspek hidup layak yang diukur melalui pengeluaran per kapita (BPS, 2019).

Penelitian tentang pembangunan manusia sudah banyak dilakukan diantaranya (Astuti, 2017) tentang analisis faktor-faktor yang mempengaruhi IPM di Provinsi Yogyakarta, (Astri et al, 2013) tentang pengaruh pengeluaran pemerintah daerah pada sektor pendidikan dan kesehatan terhadap IPM di Indonesia, dan (Insany \& Fajri, 2019) melakukan penelitian IPM di kawasan timur Indonesia. Penelitian yang sama juga dilakukan oleh (Saragih, 2018) yang melakukan penelitian tentang pengaruh pajak daerah terhadap IPM.

Capaian kualitas pembangunan manusia di Provinsi Sumatera Utara terus menunjukkan peningkatan. Pembangunan manusia di Sumatera Utara tumbuh 0,84 persen selama lima tahun terakhir. Peningkatan IPM menunjukkan bahwa kualitas hidup masyarakat Provinsi Sumatera Utara semakin tinggi. Status pembangunan manusia Sumatera Utara yang masuk kategori tinggi diikuti dengan perbaikan di beberapa indikator kesejahteraan, diantaranya penurunan tingkat kemiskinan, turunnya pengangguran dan pertumbuhan ekonomi yang terus melaju (BPS, 2019b).

IPM dipengaruhi oleh beberapa faktor diantaranya faktor sosial ekonomi. (Latuconsina, 2017) menggunakan variabel jumlah sarana kesehatan, jumlah perawat bidan dan kepadatn penduduk untuk meneliti faktor-faktor yang mempengaruhi IPM di Kabupaten Malang. (Chalid \& Yusuf, 2014) menggunakan variabel tingkat kemiskinan, tingkat pengangguran, upah minimum kabupaten kota dan laju pertumbuhan ekonomi untuk menganalisis IPM di Provinsi Riau.

Berdasarkan uraian di atas maka perlu dilakukan penelitian untuk menganalisis dan mengidentifikasi pengaruh kemiskinan, pengangguran dan produk domestik regional bruto terhadap peningkatan pembangunan manusia di Provinsi Sumatera Utara.

\section{METODE PENELITIAN}

Penelitian ini merupakan penelitian explanatory research, yaitu penelitian yang menggunakan metode yang mengidentifikasi hubungan antara variabel-variabel bebas dan variabel terikat. Penelitian ini menggunakan data sekunder yang bersumber dari publikasi yang diterbitkan oleh Badan Pusat Statistik Provinsi Sumatera Utara. Variabel yang digunakan dalam penelitian ini adalah IPM, jumlah penduduk miskin, tingkat pengangguran terbuka, pertumbuhan ekonomi dan PDRB kabupaten/kota di Provinsi Sumatera Utara pada tahun 2018. IPM merupakan salah satu indikator yang digunakan mengukur pembangunan manusia. Penghitungan IPM berdasarkan tiga dimensi yaitu dimensi umur panjang dan hidup sehat, dimensi pengetahuan dan dimensi standar hidup layak. Pencapaian IPM dapat dikelompokkan menjadi empat kategori berdasarkan tiga dimensi menurut (BPS, 2018) yang ditampilkan pada Tabel 1.

Tabel 1. Kriteria Pengelompokan IPM

\begin{tabular}{ll}
\hline Kriteria IPM & Nilai \\
\hline Sangat tinggi & IPM $\geq 80$ \\
Tinggi & $70 \leq \mathrm{IPM}<80$ \\
Sedang & $60 \leq \mathrm{IPM}<70$ \\
Rendah & IPM $<60$
\end{tabular}

Sumber: BPS Provinsi Sumatera Utara, 2018 Metode analisis data yang digunakan dalam penelitian ini adalah teknik analisis dengan banyak peubah (multivariate) yaitu analisis linier berganda. Analisis regresi linier berganda digunakan untuk melihat hubungan antara variabel prediktor dengan variabel kriteriumnya. Model persamaan linier berganda secara umum diformulasikan sebagai berikut dengan mengacu pada model 
penelitian yang dilakukan oleh (Bangun, 2018):

$\mathrm{IPM}=\alpha_{0}+\alpha_{1} \mathrm{JPM}+\alpha_{2} \mathrm{TPT}+\alpha_{3} \mathrm{PDRB}+\epsilon$

dimana :

IPM : Indeks pembangunan manusia

A : Konstanta

JPM : Jumlah penduduk miskin

TPT : Tingkat pengangguran terbuka

PDRB : Produk domestic regional bruto

$\epsilon \quad$ : error

\section{A. Uji Asumsi Klasik}

Uji Normalitas

Uji Normalitas merupakan pengujian terhadap normalitas kesalahan pengganggu/error yang digunakan untuk melihat apakah variabel bebas dan terikat dalam model berdistribusi normal.

Uji Heteroskedastisitas

Uji Heteroskesdasitas adalah uji yang digunakan untuk mengidentifikasi apakah ada ketidaksamaan varian dari residual untuk semua pengamatan pada model regresi linear. Uji ini merupakan salah satu dari uji asumsi klasik yang harus dilakukan pada regresi linear. Apabila asumsi heteroskedastisitas tidak terpenuhi, maka model regresi dinyatakan tidak valid sebagai alat peramalan. Regresi yang baik seharusnya tidak ditemukan heterokesdasitas. Pengujian heterokesdasitas dapt dilakukan dengan Uji Gletser, Uji Park dan Uji Spearman.

\section{B. Uji Multikolineritas}

Uji multikolineritas untuk menunjukkan adanya lebih dari satu hubungan linier yang sempurna. Koefisienkoefisien regresi biasanya diinterprentasikan sebagai ukuran perubahan variabel terikat jika salah satu variabel bebasnya naik sebesar satu unit dan seluruh variabel bebas lainnya dianggap tetap. Untuk mendeteksi adanya multikolinieritas adalah dengan menggunakan nilai Variance Inflation Faktor (VIF). Jika nilai VIF lebih kecil dari 10, maka dalam model tidak terdapat multikolinieritas.

\section{Uji Hipotesis}

Pengujian hipotesis secara simultan (Uji F) Pengujian signifikansi terhadap model secara simultan (bersama-sama) dimaksudkan untuk melihat kemampuan seluruh variabel bebas mampu menjelaskan
Keragaman variabel tidak bebas. Kriteria pengujian adalah sebagai berikut:

$\mathrm{H}_{0}$ : Tidak ada pengaruh secara simultan variabel jumlah penduduk miskin, tingkat pengangguran terbuka, dan nilai PDRB atas dasar harga berlaku terhadap variabel IPM di Provinsi Sumatera Utara

$\mathrm{H}_{1}$ : Ada pengaruh secara simultan variabel jumlah penduduk miskin, tingkat pengangguran terbuka, dan nilai PDRB atas dasar harga berlaku terhadap variabel IPM di Provinsi Sumatera Utara.

Kriteria pengujian sebagai berikut: Jika F-hitung lebih besar dari nilai F- tabel berarti tolak Ho terima $\mathrm{H}_{1}$.

Kesimpulan: Variabel bebas secara simultan dapat menerangkan variabel tidak bebas, sehingga model tersebut dapat digunakan.

\section{Pengujian hipotesis secara partial}

Uji ini dimaksudkan untuk menguji apakah suatu variabel bebas berpengaruh atau tidak secara nyata (signifikan) terhadap variabel tidak bebas secara partial. Kriteria pengujian sebagai berikut:

$\mathrm{H}_{0}$ : Tidak ada pengaruh secara partial variabel jumlah penduduk miskin, tingkat pengangguran terbuka, dan nilai PDRB atas dasar harga berlaku terhadap variabel IPM di Provinsi Sumatera Utara

$\mathrm{H}_{1}$ : Ada pengaruh secara partial variabel jumlah penduduk miskin, tingkat pengangguran terbuka, dan nilai PDRB atas dasar harga berlaku terhadap variabel IPM di Provinsi Sumatera Utara.

Kriteria pengujian sebagai berikut: Jika t-hitung lebih besar dari nilai t- tabel berarti tolak Ho terima $\mathrm{H}_{1}$.

Kesimpulan: Ada variabel bebas yang berpengaruh nyata terhadap variabel tidak bebas.

\section{HASIL DAN PEMBAHASAN \\ Pembangunan Manusia Provinsi Sumatera Utara}

IPM merupakan indikator capaian pembangunan kualitas hidup masyarakat yang disusun berdasarkan tiga dimensi dasar 
yaitu umur panjang dan hidup sehat, pengetahuan dan standar hidup layak (BPS, 2019). Pencapaian pembangunan manusia perlu mendapat perhatian khusus karena merupakan isu yang strategis yang sejalan dengan tujuan pembangunan berkelanjutan. Capaian pembangunan manusia di Provinsi Sumatera Utara pada tahun 2018 semakin membaik. Hal ini ditunjukkan dengan capaian IPM yang sudah mencapai 71,18. IPM Sumatera Utara meningkat sebesar 0,61 poin dibandingkan capaian pada tahun 2017.
Selama periode tahun 2014-2018, pembangunan manusia di Provinsi Sumatera Utara tumbuh rata-rata 0,84 persen per tahun. Dimensi dasar pembangunan manusia yang dibentuk oleh tiga indikator juga menunjukkan peningkatan selama periode waktu tahun 2014-2018. Capaian tersebut membawa status pembangunan manusia Sumatera Utara masuk ke kategori tinggi. Capaian pembangunan manusia Sumatera Utara selama kurun waktu tahun 2014-2018 dapat dilihat pada Tabel 2 .

Tabel 2. Perkembangan Dimensi Dasar Pembangunan Manusia Sumatera Utara Tahun 2014-2018

\begin{tabular}{|c|c|c|c|c|c|}
\hline \multirow{2}{*}{ Dimensi IPM } & \multicolumn{5}{|l|}{ Tahun } \\
\hline & 2014 & 2015 & 2016 & 2017 & 2018 \\
\hline$(1)$ & $(2)$ & $(3)$ & $(4)$ & $(5)$ & $(6)$ \\
\hline Umur Harapan Hidup (Tahun) & 68,04 & 68,29 & 68,33 & 68,37 & 68,61 \\
\hline Angka Harapan Lama Sekolah (Tahun) & 12,61 & 12,82 & 13,00 & 13,10 & 13,14 \\
\hline Rata-rata Lama Sekolah (Tahun) & 8,93 & 9,03 & 9,12 & 9,25 & 9,34 \\
\hline $\begin{array}{l}\text { Pengeluaran per kapita yang disesuaikan (juta } \\
\text { rupiah) }\end{array}$ & 9,39 & 9,56 & 9,74 & 10,04 & 10,39 \\
\hline Indeks Pembangunan Manusia (IPM) & 68,87 & 69,51 & 70,00 & 70,57 & 71,18 \\
\hline
\end{tabular}

Sumber: BPS Provinsi Sumatera Utara, 2019

Umur harapan hidup saat lahir merupakan indikator yang dapat mencerminkan derajat kesehatan suatu wilayah baik dari sarana, akses dan kualitas kesehatan (Sugiantari \& Budiantara, 2013). Umur harapan hidup saat lahir di Provinsi Sumatera Utara mencapai 68,61 yang menunjukkan rata-rata bayi yang lahir pada tahun 2018 dapat bertahan hidup sampai usia 68,61 tahun sedangkan umur harapan hidup Indonesia 71,20 tahun (BPS, 2019).

Pada aspek pendidikan, rata-rata penduduk 25 tahun ke atas di Provinsi Sumatera Utara telah menempuh pendidikan sampai 9,34 tahun atau setara dengan sudah tamat SLTP dan anak yang berusia 7 tahun yang masuk dunia pendidikan diharapkan mampu bersekolah mencapai Diploma I. Pencapaian aspek pendidikan dilihat dari indikator rata-rata lama sekolah dan harapan lama sekolah di Provinsi Sumatera Utara masih lebih rendah dibandingkan aspek pendidikan di Provinsi Kalimantan Timur (BPS, 2019a). Menurut (Berlian, 2011) ada beberapa hal yang mempengaruhi rendahnya pencapaian aspek pendidikan antara lain adalah kemiskinan, rendahnya dukungan dari pemerintah daerah serta sarana dan prasarana sekolah yang kurang memadai.

Daya beli masyarakat mencerminkan kemampuan masyarakat dalam membelanjakan uangnya dalam bentuk barang maupun jasa (Jusherni, 2013). Pada aspek ekonomi, rata-rata pengeluaran mencapai 10,39 juta rupiah per kapita per tahun. Pencapaian aspek pendidikan dan aspek ekonomi Provinsi Sumatera Utara masih lebih rendah dibandingkan dengan pencapaian Indonesia (BPS, 2019).

Seperti yang dikemukakan oleh (Lumbantoruan \& Hidayat, 2014) menjelaskan bahwa terdapat hubungan jangka panjang antara pertumbuhan ekonomi dengan pembangunan manusia di Indonesia. Peningkatan dimensi dasar pembangunan manusia di Provinsi Sumatera Utara didukung oleh beberapa faktor diantaranya pertumbuhan ekonomi wilayah yang cepat, kemajuan teknologi di bidang kesehatan serta perbaikan sarana dan prasarana di aspek kehidupan. Berdasarkan data Badan Pusat Statistik Provinsi Sumatera Utara (BPS, 2019), jumlah penduduk miskin Sumatera Utara turun sekitar 8,87 persen dari tahun 2017 sebesar 1,4 juta jiwa menjadi 1,3 juta jiwa. 
Penurunan jumlah penduduk miskin diikuti dengan penurunan tingkat pengangguran terbuka serta peningkatan pertumbuhan ekonomi Sumatera Utara dibandingkan kondisi tahun 2017.

\section{Analisis Regresi Linier Berganda}

Analisis regresi linier berganda untuk melihat pengaruh variabel jumlah penduduk miskin, tingkat pengangguran terbuka dan nilai produk domestik regional bruto atas dasar harga berlaku terhadap IPM Sumatera Utara.

\section{Uji Asumsi Klasik}

$$
\text { Hasil pengujian normalitas dengan }
$$

menggunakan Test Kolmogorov Smirnov menunjukkan bahwa data berdistribusi normal, dibuktikan dengan nilai $p$-value yang nilainya lebih besar dari nilai signifikansi 5 persen. Masalah heterokesdasitas tidak ditemukan dalam penelitian ini karena berdasarkan hasil pengujian dengan Uji Glejser tidak ditemukan ketidaksamaan varian dari semua variabel penelitian. Masalah multikolineritas juga tidak ditemukan dalam penelitian ini. Berdasrkan nilai VIF, semua variabel penelitian mempunyai nilai VIF lebih kecil dari 10. Secara lengkap hasil uji asumsi klasik dapat dilihat pada Tabel 3.

\begin{tabular}{|c|c|c|c|}
\hline \multirow[b]{2}{*}{ Variabel } & \multicolumn{3}{|l|}{ Uji Asumsi KLasik } \\
\hline & $\begin{array}{l}\text { Test Kolmogorov } \\
\text { Smirnov } \\
\text { (p-value) }\end{array}$ & $\begin{array}{l}\text { Uji Glejser } \\
\text { (p-value) }\end{array}$ & VIF \\
\hline Residual & 0,942 & & \\
\hline Jumlah penduduk miskin & & 0,76 & 3,71 \\
\hline TPT & & 0,67 & 3,15 \\
\hline PDRB & & 0,47 & 1,46 \\
\hline
\end{tabular}

Tabel 3. Hasil Uji Asumsi Klasik Analisis Regresi Linier Berganda

Sumber: Hasil pengolahan data, 2019

Hasil penelitian ini menunjukkan bahwa jumlah penduduk berpengaruh negative terhadap IPM. Pengurangan jumlah penduduk miskin akan meningkatkan capaian pembangunan manusia di Sumatera Utara. Hasil penelitian ini sejalan dengan penelitian yang dilakukan oleh (Panjaitan \& Nasution, 2015) yang menyimpulkan bahwa peningkatan IPM di Kabupaten Tapanuli Utara dipengaruhi oleh pengurangan jumlah penduduk miskin. Pemenuhan kebutuhan dasar dan akses terhadap pendidikan dan pekerjaan akan mengurangi kemiskinan yang secara tidak langsung akan berpengaruh terhadap peningkatan IPM. Chalid \& Yusuf (2014) dalam penelitiannya tentang IPM di Provinsi Riau menjelaskan bahwa tingkat kemiskinan mempengaruhi IPM sehingga jika terjadi perubahan pada jumlah penduduk miskin akan mempengaruhi IPM. Penelitian oleh (Saputra et al, 2012) tentang faktor-faktor yang mempengaruhi IPM di Provinsi Sumatera Barat menjelaskan bahwa tinggi rendahnya IPM dipengaruhi oleh perubahan jumlah penduduk miskin.

Produk domestik regional bruto (PDRB) berpengaruh secara positif terhadap IPM di Provinsi Sumatera Utara. Peningkatan PDRB perlu dilakukan karena kenaikan PDRB akan mempengaruhi kenaikan IPM. Hasil penelitian ini mendukung penelitian yang dilakukan oleh (Yuliani \& Saragih, 2014) yang melakukan penelitian tentang determinan pembangunan manusia kabupaten/kota Provinsi Jawa Tengah. Pembangunan manusia mempunyai peranan penting dalam pertumbuhan ekonomi karena pembangunan manusia merupakan salah satu input penting dalam pertumbuhan ekonomi. Selanjutnya (Setiawan \& Hakim, 2014) dalam penelitiannya tentang IPM Indonesia juga menyimpulkan bahwa PDB berpengaruh terhadap pembangunan manusia secara jangka panjang dan jangka pendek dan oleh (Bhakti et al., 2014) dalam penelitiannya tentang analisis faktor-faktor yang mempengaruhi IPM di Indonesia juga 
menyimpulkan bahwa PDB dan pertumbuhan ekonomi sangat diperlukan dalam peningkatan IPM.

Uji hipotesis

Persamaan regresi linier berganda

Persamaan linier berganda dari hasil pengujian sebagai berikut:

$\mathrm{Y}=3,79-0,101 \mathrm{JPM}+0,0102 \mathrm{TPT}+0,0844$ $\mathrm{PDRB}+\epsilon$

Nilai konstanta 3,79 menunjukkan bahwa IPM di Provinsi Sumatera Utara sebesar 3,79 persen jika tidak ada pengaruh dari variabel jumlah penduduk miskin, tingkat pengangguran terbuka dan produk domestik regional bruto atas dasar harga berlaku. Persamaan 2 menunjukkan bahwa variabel jumlah penduduk miskin, tpt dan nilai produk domestik regional bruto atas dasar harga berlaku memberikan pengaruh yang berbeda terhadap IPM. Setiap penurunan satu persen jumlah penduduk miskin akan meningkatkan IPM sebesar 0,101 persen dengan asumsi variabel yang lain konstan. Kenaikan satu persen tingkat pengangguran terbuka akan menaikkan 0,0102 persen IPM dengan asumsi variabel yang lain konstan. Kenaikan produk domestik regional bruto atas dasar harga berlaku sebesar satu persen akan menaikkan 0,0844 persen IPM dengan asumsi variabel yang lain konstan. Hasil penelitian ini sama dengan penelitian yang dilakukan oleh (Heriyanto, 2015) dimana variabel PDRB dan jumlah penduduk miskin berpengaruh terhadap IPM kabupaten/kota di Provinsi Kalimantan Barat.

\section{Koefisien determinasi $\left(\mathbf{R}^{2}\right)$}

Hasil penghitungan koefisien determinasi $\left(\mathrm{R}^{2}\right)$ sebesar 0,6273 yang berarti bahwa pengaruh variabel jumlah penduduk miskin, tingkat pengangguran terbuka dan nilai produk domestik regional bruto atas dasar harga berlaku terhadap IPM Sumatera Utara sebesar 62,73 persen sedangkan 37,27 persen dipengaruhi oleh variabel di luar model.

\section{Uji secara simultan (Uji F)}

Hasil pengujian secara simultan menunjukkan bahwa nilai $\mathrm{F}$ dihitung sebesar 18,95 dengan $p$-value sebesar 0,000. Nilai p-value lebih kecil dari nilai signifikansi uji sehinga dapat disimpulkan bahwa secara simultan variabel jumlah penduduk miskin, tingkat pengangguran terbuka dan nilai produk domestik regional bruto atas dasar harga berlaku berpengaruh terhadap terhadap IPM Sumatera Utara.

\section{Uji secara partial (Uji T)}

Hasil pengujian secara partial menunjukkan bahwa dari ketiga variabel jumlah penduduk miskin, tingkat pengangguran terbuka dan nilai produk domestik regional bruto atas dasar harga berlaku hanya variabel tingkat pengangguran terbuka yang tidak berpengaruh signifikan terhadap IPM Sumatera Utara sedangkan variabel jumlah penduduk miskin dan nilai produk domestik regional bruto atas dasar harga berlaku berpengaruh secara nyata terhadap indek pembangunan manusia di Sumatera Utara.

Tabel 4. Hasil Analisis Regresi Linier Berganda

\begin{tabular}{llll}
\hline Variabel bebas & Coefficient & t-statistik & signifikansi \\
\hline Constant & 3,7912 & 49,43 & 0,000 \\
\hline Jumlah penduduk miskin & $-0,101$ & $-5,4446$ & 0,000 \\
\hline Tingkat pengangguran terbuka & 0,0102 & 0,9357 & 0,3572 \\
\hline $\begin{array}{l}\text { Produk domestik regional bruto atas dasar harga } \\
\text { berlaku }\end{array}$ & 0,0844 & 6,4511 & 0,000 \\
\hline R2 & & & \\
\hline Adjusted R2 & 66,23 & & \\
\hline F statistic & 62,73 & & \\
\hline Prob F-statistic & 18,95 & & \\
\hline Sumber: Hasl pengon & & & \\
\hline
\end{tabular}

Sumber: Hasil pengolahan data, 2019

Tingkat pengangguran terbuka tidak berpengaruh secara signifikan terhadap IPM di Provinsi Sumatera Utara. Hasil penelitian ini didukung penelitian yang dilakukan oleh 
(Noviatamara et al., 2019) tentang analisis pengaruh pertumbuhan ekonomi dan tingkat pengangguran terbuka di Yogyakarta. Pengangguran tidak berpengaruh secara signifikan terhadap capaian pembangunan manusia tetapi tetap berperan dalam peningkatan pembangunan manusia. Juga (Baeti, 2013) dalam penelitiannya tentang pengaruh pengangguran, pertumbuhan ekonomi, dan

\section{SIMPULAN}

Hasil analisis menunjukkan bahwa status pembangunan manusia di Provinsi Sumatera Utara terus menunjukkan peningkatan. Kemiskinan, pengangguran dan PDRB atas dasar harga berlaku memberikan pengaruh terhadap peningkatan IPM. Secara partial kemiskinan dan produk domestik regional bruto atas dasar harga berlaku memberikan pengaruh yang signifikan sedangkan pengangguran tidak berpengaruh signifikan terhadap peningkatan IPM di Provinsi Sumatera Utara.

\section{DAFTAR PUSTAKA}

Astri, M., NIkensari, S. I., \& W, H. K. (2013). Pengaruh Pengeluaran Pemerintah Daerah Pada Sektor Pendidikan Dan Kesehatan Terhadap Indeks Pembangunan Manusia Di Indonesia. Jurnal Pendidikan Ekonomi Dan Bisnis, 1(1), 77-102.

Astuti, M. (2017). Analisis Faktor-Faktor Yang Mempengaruhi Indeks Pembangunan Manusia Di Provinsi Daerah Istimewa Yogyakarta. Universitas Islam Indonesia.

Baeti, N. (2013). Pengaruh Pengangguran, Pertumbuhan Ekonomi, Dan Pengeluaran Pemerintah Terhadap Pembangunan Manusia Kabupaten/Kota di Provinsi Jawa Tengah. Economics Development Analysis Journal, 2(3), 85-98.

Bangun, R. H. (2018). Determinan Produksi Ikan Tangkap Di Kota Sibolga. Jurnal Agrica, 11(1), 28-38.

Berlian VA, N. (2011). Faktor-faktor yang Terkait dengan Rendahnya Pencapaian Wajib Belajar Pendidikan Dasar 9 Tahun. Jurnal Pendidikan Dan Kebudayaan, 17(1), 4357.

Bhakti, N. A., Istiqomah, \& Suprapto. (2014). Analisis Faktor-Faktor Yang Mempengaruhi Indeks Pembangunan pengeluaran pemerintah terhadap pembangunan manusia kabupaten/kota di Provinsi Jawa Tengah Tahun 2007-2011 menjelaskan bahwa pengangguran berkaitan erat dengan tingkat pendapatan yang merupakan salah satu faktor yang menentukan kualitas pembangunan manusia. Oleh (Fatimah, 2018) pengangguran berkaitan erat dengan kualitas pembangunan manusia. Manusia Di Indonesia. Ekuitas: Jurnal Ekonomi Dan Keuangan, 18(4), 452-469.

BPS. (2019a). Indeks Pembangunan Manusia 2018. Jakarta: Badan Pusat Statistik.

BPS. (2019b). Provinsi Sumatera Utara Dalam Angka. Medan: Badan Pusat Statistik Provinsi Sumatera Utara.

Chalid, N., \& Yusuf, Y. (2014). Pengaruh Tingkat Kemiskinan dan Tingkat Pengangguran, Upah Minimun Kabupaten/Kota Dan Laju Pertumbuhan Ekonomi Terhadap Indeks Pembangunan Manusia di Provinsi Riau. Jurnal Ekonomi, 22(2), 1-12.

Fatimah, S. N. (2018). Analisis Pengaruh Kemiskinan, Pengangguran, Pertumbuhan Ekonomi Terhadap Indeks Pembangunan Manusia di Provinsi Banten Tahun 20102015. Universitas Islam Indonesia.

Heriyanto, D. (2015). Analisis Faktor-Faktor Yang Mempengaruhi Indeks Pembangunan Manusia (Ipm) Kabupaten / Kota Di Provinsi Kalimantan Barat Tahun 2006-2010. Jurnal Ekonomi Daerah, 3(1), 1-18.

Insany, A. N., \& Fajri, M. (2019). Pemodelan IPM Di Kawasan Timur Indonesia Menggunakan Multivariate Adaptive Regression Spline ( MARS ). Natural Science, 08(02), 94-98.

Juliarini, A. (2019). Kinerja Pendapatan Daerah Terhadap Indeks Pembangunan Manusia Studi Kasus Provinsi Di Pulau Jawa. Simposium Nasional Keuangan Negara, 15(1), 934-957.

Jusherni. (2013). Analisis Segmentasi Gaya Hidup Pada Mahasiswa Jurusan Manajemen S1 Fakultas Ekonomi Universitas Riau. Journal of Chemical Information and Modeling, 21(1), 1-17.

Latuconsina, Z. M. Y. (2017). Analisis Faktorfaktor yang Mempengaruhi Indeks Pembangunan Manusia Kabupaten Malang Berbasis Pendekatan Perwilayahan dan Regresi Panel. Journal of Regional and Rural Development Planning, 1(2), 202216. 
Lumbantoruan, E. P., \& Hidayat, P. (2014). Analisis Pertumbuhan Ekonomi Dan Indeks Pembangunan Manusia (Ipm) Provinsi-Provinsi Di Indonesia (Metode Kointegrasi). Jurnal Ekonomi Dan Keuangan, 2(2), 14-29.

Melliana, A., \& Zain, I. (2013). Analisis Statistika Faktor yang Mempengaruhi Indeks Pembangunan Manusia di Kabupaten/Kota Provinsi Jawa Timur dengan Menggunakan Regresi Panel. Jurnal Sains Dan Seni POMITS, 2(2), 237242.

Noviatamara, A., Ardina, T., \& Amalia, N. (2019). Analisis Pengaruh Pertumbuhan Ekonomi Dan Tingkat Pengangguran Terbuka Di Daerah Istimewa Yogyakarta. Jurnal REP (Riset Ekonomi Pembangunan), 4(1), 5360.

Panjaitan, L., \& Nasution, H. (2015). Aplikasi Analisis Jalur Dalam Menganalisis FaktorFaktor Yang Mempengaruhi Indeks Pembangunan Manusia Kabupaten Tapanuli Utara. Karismatika, 1(3), 97-108.

Saputra, B. F. S., Karimi, K., \& Helmawati. (2012). Faktor-Faktor Yang Mempengaruhi Indeks Pembangunan Manusia Di Provinsi Sumatera Barat. Jurnal Fakultas Ekonomi, 9(3), 1-14.

Saragih, A. H. (2018). Analisis Pengaruh Penerimaan Pajak Daerah Terhadap Indeks Pembangunan Manusia. Jurnal Economica, 14(2), 197-211.

Sari, F. W., \& Bangun, R. H. (2019). Pengaruh Sosial Ekonomi Terhadap Pola Penurunan Pengangguran Terbuka Di Provinsi Sumatera Utara Tahun 2003-2017. Jurnal Nusantara, 6(1), 31-40.

Setiawan, M. B., \& Hakim, A. (2014). Indeks Pembangunan Manusia Indonesia. Jurnal Economia, 9(1), 18-26.

Sugiantari, A. P., \& Budiantara, I. N. (2013). Analisis Faktor-faktor yang Mempengaruhi Angka Harapan hidup di Jawa Timur menggunakan Regresi Semiparametrik Spline. Jurnal Sains Dan Seni ITS, 2(1), 37-41.

Yuliani, T., \& Saragih, N. (2014). Determinan Pembangunan Manusia di Kabupaten/kota Provinsi Jawa Tengah. Journal of Economic and Policy, 7(1), 6072 . 